\title{
The Influence of PDEODE Learning Model and 5M Scientific with High Order Thinking Skills against Students Chemical Literacy
}

\author{
Sukro*, Afrizal, Rika Afritasari \\ Department of Chemistry Education \\ Universitas Negeri Jakarta \\ Jakarta, Indonesia \\ sukro_muhab@yahoo.com
}

\begin{abstract}
The purpose of this research are to know the influence of learning models (PDEODE and 5M) and critical thinking skills on students' chemical literacy. The population of the research were students of State Senior High School 5 Jakarta. The research instrument used are critical thinking test and chemical literacy test in buffer solution course. Chemical literacy test results were analyzed using two-way ANAVA method, then continued with Tuckey test at a significance level of $5 \%$. The result of the research can be conclude that: 1) The students' chemical literacy using PDEODE learning model is higher than $5 \mathrm{M}$ learning model. 2) There is no significant interaction effect between learning models and hihgh order thinking skills to chemical literacy. 3) The students' chemical literacy with PDEODE are higher than $5 \mathrm{M}$ learning model for high-critical thinking groups.
\end{abstract} literacy

Keywords - PDEODE, High order thingking skill, chemical

\section{INTRODUCTION}

At present, the people in Indonesia are faced with the tighter competition in the working world since the holding of the ASEAN Economic Community (AEC). This indicates that manpower in Indonesia is not only from the natives, but also from ASEAN member countries. Therefore, it is important for us to prepare ourselves so that we cannot compete in our own country due to the AEC. One of the ways of the government in overcoming this, especially in the field of education is to produce graduates who have qualifications, have talent, and have good skills. This is in accordance with the Graduates Competency Standards set forth in Regulation of Ministry Education and Culture number 20 of 2016 that the qualifications of Indonesian graduates' ability are expected to cover three domains, namely attitudes, knowledge and skills of each education unit. The birth of competent human resources will help the government to improve the quality of life of its people and become a more developed country in order to be able to answer the challenges of the 21 st century.

In the 21st century, humans are required to have an awareness of global conditions, have high creativity and innovation, have high order thinking skills (HOTS) to be able to solve problems, have good communication and collaboration skills, and have good literacy skills (the partnership for 21 st century skills, 2009). Scientific literacy skills are important for students' thinking development because every human being needs a scientific thinking process to make a decision, it needs to involve his ability in public discourse to understand and be able to argue on important issues involving science and technology [1]

But in fact, student science literacy in Indonesia is still low. This is evidenced by the data from the assessment conducted by PISA (Program for International Student Assessment) to show students' scientific and mathematical literacy ratings in the world. Based on the results of the PISA assessment to measure student literacy in science in 2000 , Indonesia ranks 38th out of 41 countries, in 2003 ranked 38th out of 40 countries, in 2006 ranked 53th out of 57 countries, in 2009 to 38 th out of 40 the country and 2012 ranked 64th out of 65 countries while in 2015, the scientific literacy ranking of Indonesian students ranked 66th out of 74 participating countries [2]. Based on these data, it can be seen that Indonesia is ranked 2 to 7 from the lowest rank compared to other countries. The low level of scientific literacy in Indonesia indicates that students in Indonesia have low thinking and analytical skills seen from the students' answers to overcome a problem-based problem. This is because the learning process has not implemented meaningful learning, so it is difficult for students to develop their critical thinking skills [3]

High order thinking skills (HOTS) is a process that allows a person to examine an evidence and provide assumptions based on the opinions and logic of the statements of others so as to gain deep understanding [4]. High order thinking skills (HOTS) are not necessarily present in a person from birth, but must be developed and improved in everyday life. Therefore, in learning students should be guided by the teacher so that they are accustomed to analyzing problems, collecting information as outlined in the hypothesis, looking for relevant sources of information, then students can prove the results of the hypothesis based on the results of the experiment [5].

This is in line with Susanto's statement [6] which states that the ability to think students' level of criticism can be realized if there is an interactive class by making students as thinkers to get their own knowledge, while teachers only act as facilitators, mediators and motivators for students in the learning process. Therefore, education providers, especially teachers, are required to strive to innovate in learning in order to develop high order thinking skills (HOTS) so as to improve scientific literacy. One way to develop students' scientific literacy is to review the learning process in school. One of the things that can be done by the teacher is preparing learning using the right learning model in order to improve 
scientific literacy. Based on previous research, one of the learning models that can influence students' critical thinking skills is the PDEODE (Predict-Discuss-Explain-ObserveDiscuss-Explain) learning model [7].

The PDEODE learning model is the result of the development and modification of the POE (Predict-ObserveExplain) learning model which has the characteristics of cyclical learning models [8]. POE learning model is based on constructivism theory which states that learning is a process of knowledge formation carried out by students [9]. PDEODE learning model is learning that is designed so that students can discuss and give arguments based on their perspective. Students are expected to be able to actively engage in thinking, processing concepts and interpreting the learning process.

The application of the learning model must also pay attention to the characteristics of the material to be taught so that the learning objectives are maximally achieved. As good as any learning model, if the application is not in accordance with the characteristics of the material it will make the desired competency not achieved. Chemical material suitable for PDEODE learning model one of them is buffer solution material [10]. This is because this material is able to improve problem solving skills both at the macroscopic, microscopic and symbolic levels. The macroscopic level of the buffer solution material includes the nature and change of solution, the microscopic level includes the interaction between atoms and molecules in the buffer solution, while for the symbolic level, it is related to the $\mathrm{pH}$ calculation of the buffer solution using symbols, symbols, and solution curves. Therefore, the buffer solution material was chosen to be studied in the study to analyze how the influence of PDEODE learning model and high order thinking skills (HOTS) on chemical literacy.

\section{METHOD}

This study uses a quasi-experimental method with the Posttest-Only Control Design. This study uses two independent variables, namely the learning model as a treatment variable and high-level thinking ability (HOTS) as an attribute variable. In each independent variable is divided into two types, the learning model is PDEODE and $5 \mathrm{M}$ as a factor A, while the ability to think as a factor B is divided into two groups, namely high-level thinking ability (HOTS) and low-level thinking skills (LOTS). The dependent variable used is the ability of chemical literacy in terms of cognitive aspects. Therefore, this study uses a 2 × 2 factorial design. The description of the research method is illustrated in table I.

TABLE I. DESCRIPTION OF RESEARCH METHODS

\begin{tabular}{|c|c|c|}
\hline \multirow{2}{*}{$\begin{array}{c}\text { Thinking Ability } \\
\text { (B) }\end{array}$} & \multicolumn{2}{|c|}{ Learning Models (A) } \\
\cline { 2 - 3 } & PDEODE $\left(\mathrm{A}_{1}\right)$ & $5 \mathrm{M}\left(\mathrm{A}_{2}\right)$ \\
\hline $\begin{array}{c}\text { High Order } \\
\text { Thinking Skills } \\
\text { (HOTS) (B })\end{array}$ & $\mathrm{A}_{1} \mathrm{~B}_{1}$ & $\mathrm{~A}_{2} \mathrm{~B}_{1}$ \\
\hline $\begin{array}{c}\text { Low Order } \\
\text { Thinking Skills } \\
\left.\text { (LOTS) (B } \mathrm{B}_{2}\right)\end{array}$ & $\mathrm{A}_{1} \mathrm{~B}_{2}$ & $\mathrm{~A}_{2} \mathrm{~B}_{2}$ \\
\hline
\end{tabular}

The population in this study were students of class XI Science in SMAN 5 Jakarta in the even semester of 2017/1981 academic year. Sampling in this study was using simple random sampling technique or random sample selection, where the population had the same opportunity to be used as research samples [11]. The sample chosen is class XI IPA 3 which is used as an experimental class with treatment using the PDEODE learning model, while class XI IPA 4 is used as a control class given traditional learning. The number of students sampled was 36 students where each class consisted of 18 students.

The research instrument consisted of (1) critical thinking ability test in the form of 30 multiple choice questions to measure students 'low thinking abilities and (2) chemical literacy tests in the form of 12 questions to measure students' chemical literacy after treatment was given using the PDEODE learning model and 5M. Before being used, chemical literacy instruments were validated by two content validity experts and tested to determine their validity and reliability. Calculation of the validation of the item is determined by the Pearson Product Moment formula and the results are obtained with 12 valid questions. After that the problem was tested for reliability using the Alpha Cronbacht formula and obtained reliability values of 0.9487 with a very high level of reliability.

\section{RESULTS AND DISCUSSION}

\section{A. Research Result}

The results data from this study are data on the value of students' thinking ability and data on the value of chemical literacy in the buffer solution chapter. Then the data from this study are grouped into (1) students 'chemical literacy data given the learning model (A1 and A2), (2) students' chemical literacy data given the PDEODE model with high order thinking skills to see differences in learning outcomes of students who have the ability to think high and low level on the application of PDEODE and 5M learning models.

(HOTS) high (A1B1), (3) students 'chemical literacy data given the PDEODE model with low level thinking ability (LOTS) namely (A1B2), students' chemical literacy data given the $5 \mathrm{M}$ model with high level thinking ability (HOTS) namely ( A2B1), students' chemical literacy data were given a $5 \mathrm{M}$ model with low level thinking ability (LOTS) namely (A2B2). Description of chemical literacy data and standard deviations is presented in table II.

TABLE II. THE MEAN AND STANDARD DEVIATION OF TREATMENT GROUPS

\begin{tabular}{|c|c|c|c|c|c|}
\hline Goups & $\mathrm{N}$ & Mean & $\begin{array}{c}\text { Deviation } \\
\text { Standart }\end{array}$ & $\begin{array}{c}\text { Minimum } \\
\text { Score }\end{array}$ & $\begin{array}{c}\text { Maximum } \\
\text { Score }\end{array}$ \\
\hline $\mathrm{A}_{1}$ & 18 & 76.44 & 9.9 & 60 & 94 \\
\hline $\mathrm{A}_{2}$ & 18 & 63.78 & 8.9 & 50 & 88 \\
\hline $\mathrm{A}_{1} \mathrm{~B}_{1}$ & 9 & 83.78 & 5.7 & 78 & 94 \\
\hline $\mathrm{A}_{1} \mathrm{~B}_{2}$ & 9 & 69.11 & 6.2 & 60 & 82 \\
\hline $\mathrm{A}_{2} \mathrm{~B}_{1}$ & 9 & 68.89 & 9.2 & 58 & 88 \\
\hline $\mathrm{A}_{2} \mathrm{~B}_{2}$ & 9 & 58.67 & 5.3 & 50 & 66 \\
\hline
\end{tabular}

Based on table II, the mean results of students' chemical literacy tests treated with the PDEODE (A1) 
learning model were higher than the group of students treated with the $5 \mathrm{M}$ model (A2). The results of the chemical literacy test group of students who were treated with PDEODE (A1B1) had the highest average compared to other groups, this was supported by the minimum score data and the maximum score of the chemical literacy test and low standard deviation. Before testing the hypothesis, the six groups were tested for analysis prerequisites namely normality test and homogeneity test. Data normality test using the Liliefors test. Recapitulation of data on the results of normality tests is presented in table III. A data is said to be normally distributed if the value of Calculate $<$ Ltable so that $\mathrm{H} 0$ is accepted. The results of the normality test of chemical literacy of all groups have a lower Lcount value Ltable so that it can be concluded that all sample groups come from populations that are normally distributed.

TABLE III. RECAPITULATION OF NORMALITY TEST OF STUDENTS' CHEMICAL LITERACY TEST DATA WITH THE LILIEFORS TEST AT A SIGNIFICANCE LEVEL A $=0.05$

\begin{tabular}{|c|c|c|c|c|}
\hline $\begin{array}{c}\text { Sample } \\
\text { Group }\end{array}$ & $\begin{array}{c}\text { Total } \\
\text { Sample }\end{array}$ & $\mathrm{L}_{\text {hitung }}$ & $\mathrm{L}_{\text {tabel }}$ & Conclusion \\
\hline $\mathrm{A}_{1}$ & 18 & 0.1356 & 0.200 & Normal \\
\hline $\mathrm{A}_{2}$ & 18 & 0.1525 & 0.200 & Normal \\
\hline $\mathrm{A}_{1} \mathrm{~B}_{1}$ & 9 & 0.2617 & 0.271 & Normal \\
\hline $\mathrm{A}_{1} \mathrm{~B}_{2}$ & 9 & 0.2381 & 0.271 & Normal \\
\hline $\mathrm{A}_{2} \mathrm{~B}_{1}$ & 9 & 0.2184 & 0.271 & Normal \\
\hline $\mathrm{A}_{2} \mathrm{~B}_{2}$ & 9 & 0.1184 & 0.271 & Normal \\
\hline
\end{tabular}

Homogeneity test is performed using the Bartlett test. Homogeneity testing with the Bartlett test on four cells namely A1B1, A1B2, A2B1, and A2B2 with a significance level of $\alpha=0.05$ can be seen in table 4 as follows.

TABLE IV. THE RESUlts OF THE BARTLETT TEST CALCULATION

\begin{tabular}{|c|c|c|c|c|c|}
\hline $\begin{array}{c}\text { Group } \\
\text { Sample }\end{array}$ & $\mathrm{dk}=\mathrm{n}-1$ & $\mathrm{~S}^{2}$ & $\log \mathrm{S}^{2}$ & $\mathrm{dk} . \mathrm{S}^{2}$ & $\mathrm{dk} \cdot \log \mathrm{S}^{2}$ \\
\hline $\mathrm{A}_{1} \mathrm{~B}_{1}$ & 8 & 32.4444 & 1.51114 & 259.5556 & 12.08912 \\
\hline $\mathrm{A}_{1} \mathrm{~B}_{2}$ & 8 & 56.1111 & 1.749049 & 448.8889 & 13.99239 \\
\hline $\mathrm{A}_{2} \mathrm{~B}_{1}$ & 8 & 84.1111 & 1.924853 & 672.8889 & 15.39883 \\
\hline $\mathrm{A}_{2} \mathrm{~B}_{2}$ & 8 & 35.1111 & 1.545445 & 280.8889 & 12.36356 \\
\hline Total & 32 & & 6.730487 & 1662.222 & 53.8439 \\
\hline
\end{tabular}

Based on the calculation of the Bartlett test on the four data groups, obtained chi-square count $\mathrm{X} 2$ count $=2.42$. the chi-square value of the table at the significance level $\alpha=$ 0.05 was obtained $\mathrm{X} 2$ table $=7.815$. Thus, $\mathrm{X} 2$ counts $<\mathrm{X} 2$ table which indicates $\mathrm{H} 0$ is accepted, so it can be concluded that the four data groups have homogeneous variance.

After the data obtained has fulfilled the analysis prerequisite test, then hypothesis testing is done using twoway ANAVA. The recapitulation of ANAVA test results is presented in table 5. Based on the calculation results, Fcount $=28.784$ (between the PDEODE and 5M learning models) is greater than Ftable $=4.15$ at a significance level of 0.05 . This indicates that the first hypothesis is declared H0 rejected and $\mathrm{H} 1$ is accepted, so it can be concluded that there is a significant difference in the value of chemical literacy between students who are given the PDEODE learning model and the traditional learning model. Furthermore, based on the results of the calculation of the interaction between the learning model and students' thinking ability toward chemical literacy, the value of Fcount $=0.886$ was smaller than that of Ftable $=4.15$ at a significance level of 0.05 . This result indicates that the second hypothesis is $\mathrm{H} 0$ is accepted and $\mathrm{H} 1$ is rejected. That is, there is no significant interaction effect between the learning model and the ability to think on students' chemical literacy.

TABLE V. RECAPITULATION OF TWO TRACK ANAVA RESUlts

\begin{tabular}{|c|c|c|c|c|c|c|}
\hline $\begin{array}{c}\text { Varians } \\
\text { Source }\end{array}$ & $\mathrm{Db}$ & $\mathrm{JK}$ & $\mathrm{RJK}$ & $\mathrm{F}_{\mathrm{h}}$ & $\begin{array}{c}\mathrm{F}_{\mathrm{t}} \\
(\alpha=0,05)\end{array}$ & Explanation \\
\hline $\begin{array}{c}\text { Between } \\
\text { Coloumns } \\
\text { (A) } \\
\text { Learning } \\
\text { Models }\end{array}$ & 1 & 1444 & 1444 & 28.784 & 4.15 & significant \\
\hline $\begin{array}{c}\text { Between } \\
\text { Row (B) } \\
\text { Critical } \\
\text { Thinking }\end{array}$ & 1 & 1393.778 & 1393.778 & 27.783 & 4.15 & significant \\
\hline $\begin{array}{c}\text { Interaction } \\
\text { (A>B }>\text { B } \\
\text { Learning } \\
\text { Model >< } \\
\text { Critical } \\
\text { Thinking }\end{array}$ & 1 & 44.444 & 44.444 & 0.886 & 4.15 & $\begin{array}{c}\text { not } \\
\text { significant }\end{array}$ \\
\hline $\begin{array}{c}\text { In Groups } \\
\text { (D) }\end{array}$ & 32 & 1605.333 & 960.741 & & & \\
\hline Total (TR) & 35 & 4487.556 & & & & \\
\hline
\end{tabular}

The pattern of interaction between students and chemical literacy is shown in the following figure

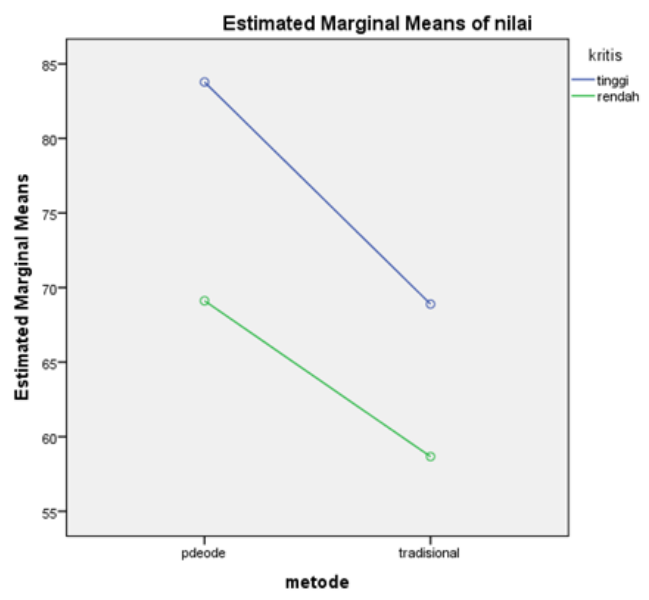

Fig. 1. The pattern of interaction between the learning model and the students' ability to think about chemical literacy

Based on the image of the interaction pattern, the line between the learning model and the ability to think students are parallel or not intersect, meaning that there is no interaction between learning models and critical bepriki abilities towards chemical literacy. Tuckey Test was then conducted to determine the significance of differences in mean chemical literacy students who had high-level 
thinking ability (HOTS) between students who were given PDEODE and 5M learning models (A1B1 and A2B1) and students who had low-level thinking skills (LOTS) modeled PDEODE and 5M learning (A1B2 and A2B2). Further test results from the two treatment groups are presented in the table.

TABLE VI. SUMmary OF TUCKEy TEST RESUltS

\begin{tabular}{|c|c|c|}
\hline Groups & \multirow{2}{*}{ Q $_{\text {hitung }}$} & $\mathrm{Q}_{\text {tabel }}$ \\
\cline { 1 - 1 } $\mathrm{A}_{1} \mathrm{~B}_{1}$ & \multirow{2}{*}{6.31} & 4.41 \\
\cline { 1 - 1 } $\mathrm{A}_{2} \mathrm{~B}_{1}$ & & \\
\cline { 1 - 2 } $\mathrm{A}_{1} \mathrm{~B}_{2}$ & \multirow{2}{*}{4.42} & 4.41 \\
\cline { 1 - 2 } $\mathrm{A}_{2} \mathrm{~B}_{2}$ & & \\
\hline
\end{tabular}

Based on the results of calculations using the Tukey test given above, the value of $\mathrm{Qh}>\mathrm{Qt}$. That is, the third hypothesis shows that $\mathrm{H} 0$ is rejected and $\mathrm{H} 1$ is accepted or it can be concluded that there are significant differences in the value of chemical literacy between those given the PDEODE and 5M learning models in groups of students with high order thinking abilities (HOTS). the fourth hypothesis also produces $\mathrm{H} 0$ rejected and $\mathrm{H} 1$ is accepted, or there is a significant difference in chemical literacy between those given the PDEODE and 5M learning models in groups of students with low order thinking skills (LOTS).

\section{B. Discussion of Research Results}

Based on the results of the first hypothesis test, shows that the Fcount value is greater than the Ftable value at the significance level of 0.05 so that $\mathrm{H} 0$ is rejected and $\mathrm{H} 1$ is accepted. That is, the value of chemical literacy students who are taught using the PDEODE learning model is better than the value of students' chemical literacy taught with the $5 \mathrm{M}$ learning model. The PDEODE learning model and the $5 \mathrm{M}$ learning model are two different models in terms of learning steps. In PDEODE learning there are learning steps such as predicting a topic of the problem to be studied. So the ability to analyze students becomes more developed. This is what can affect students' chemical literacy.

This is in accordance with the opinion of Costu [9] which states that the PDEODE learning model can develop students' concept mastery of problems that occur in everyday life so that students become better at analyzing a problem. When learning using the PDEODE learning model, students construct their own knowledge through scientific activities related to everyday life while the teacher is only a facilitator. In contrast to traditional learning models that need teacher guidance in learning so students are less active in learning. This finding is similar to the research conducted by Solichah et al. [12] where the PDEODE learning model can improve learning outcomes in understanding the concept better and Tismi's research (2016) which shows that the PDEODE strategy can influence students' high order thinking (HOTS).

The findings of this study state that in the results of the second hypothesis test, there is no significant interaction between learning models and high-level thinking skills (HOTS) on chemical literacy. The absence of interaction occurs because based on the value of chemical literacy, groups that use the PDEODE learning model with high high-level thinking skills (HOTS) and high-level thinking (HOTS) are low (A1B1 and A1B2) have a higher average value compared to groups of students who use the $5 \mathrm{M}$ learning model (A2B1 and A2B2). This is what makes no interaction between learning models with critical thinking skills. This means that when learning takes place, the class treated using the PDEODE learning model provides a stimulus to good students with high level thinking skills (HOTS) and high level thinking skills (HOTS) so that this experimental class has a higher value of chemical literacy compared to control class. PDEODE learning makes the classroom environment more meaningful and realistic so that it can improve students' understanding of concepts and learning outcomes [13].

The experimental class given the PDEODE learning model became more active in arguing, competing in expressing opinions such as in predicting a problem, having more discussion, observing to analyze the truth of a topic through practicum then concluding learning outcomes so that knowledge was obtained based on demanding learning processes. their high level thinking skills (HOTS) to be developed. Whereas in the control class that uses a $5 \mathrm{M}$ learning model (based on an improved 2013 curriculum), it looks less active in the learning process because students are accustomed to being instructed by the teacher so that students are less motivated to develop their critical thinking skills, class conditions that do not appear competitive in expressing opinions making students 'analytical abilities low so that students' chemical literacy becomes lower than the experimental class.

The results of the third hypothesis test state that $\mathrm{H} 0$ is rejected and $\mathrm{H} 1$ is accepted, then there are differences in the value of chemical literacy students who are taught using the PDEODE and 5M learning models in groups of students who have high-level thinking skills (HOTS). The results of the third hypothesis test concluded that the group of students who used the PDEODE learning model with high-level thinking skills (HOTS) had a higher value of chemical literacy than the group that used the $5 \mathrm{M}$ learning model with high-level thinking skills (HOTS). This indicates that the ability to think has an important role in improving student literacy. Students who have high-level thinking skills (HOTS) are increasingly developing their analytical skills because the learning process uses the PDEODE learning model so as to make students more active in discussing and expressing their ideas.

The results of the fourth hypothesis test state that there are differences between the values of students' chemical literacy who are taught using the PDEODE and 5M learning models in groups of students who have low-level thinking skills (LOTS). However, the difference in question is that the value of chemical literacy in the group of students who use the PDEODE learning model is higher than the group of students who use the $5 \mathrm{M}$ model. Supposedly, students who use the 5M learning model with thinking skills (LOTS) have higher literacy values than students who use the PDEODE learning model with low abilities.

According to Tismi (2016) the learning process using the PDEODE model allows students the opportunity to express their opinions about their initial knowledge and provide opportunities for students to work together in discussing and arguing. The treatment between groups of students who 
have high and low thinking abilities in the class has an impact on students' chemical literacy results so that groups of students who use the PDEODE model with low thinking ability have higher average scores compared to the two groups of students who use the $5 \mathrm{M}$ learning model who have high or low level thinking skills.

\section{CONCLUSION}

Based on the results of this study, the following conclusions were obtained. First, there are differences in students' chemical literacy using the PDEODE learning model with the $5 \mathrm{M}$ learning model. The average value of students 'chemical literacy who participated in PDEODE learning was higher than the average value of students' chemical literacy who took $5 \mathrm{M}$ learning. Second, there is no interaction between the learning model and students 'ability to think about students' chemical literacy. Third, there are differences in chemical literacy with the ability to think between students who use the PDEODE learning model and students who use the $5 \mathrm{M}$ learning model. The average value of chemical literacy with high level thinking ability (HOTS) that follows PDEODE learning is higher than students who take $5 \mathrm{M}$ learning. Fourth, there are differences in chemical literacy with low-level thinking skills (LOTS) between students who use the PDEODE learning model and students who use the $5 \mathrm{M}$ learning model. The average value of chemical literacy with low level thinking ability (HOTS) that follows PDEODE learning is higher than students who take 5M learning, which means that the PDODE learning approach has a huge influence on students' literacy skills in chemistry learning.

\section{ACKNOWLEDGMENT}

Thank you for all the support for this research group, and headmaster SMAN 5 Jakarta.

\section{REFERENCES}

[1] Cigdemoglu, Ceyhan \& Omer. Improving Students Chemical Literacy Level on Thermochemical and Thermodynamics Concepts Through Context-Based Approach. 2015. Chem. Educ. Res. Pract, 16, 302317.

[2] Organization for Economic Co-operation and Development (OECDPISA). 2016. Assessment of scientific literacy in the OECD / Pisa project, http://www.pisa.oecd.org/

[3] Dharma, S. "the development of Teachers and Education Personnel Facing the Challenges of the 21st Century" (Pembangunan Pendidik dan Tenaga Kependidikan Menghadapi Tantangan Abad 21). 2008. Paper presented at a Public Lecture for State University of Malang Graduate Student Academic Year 2008/2009. Malang, August 27.

[4] Johnson, Elaine B. Contextual Teaching \& Learning. Bandung: Kaifa. 2010.

[5] Muharamiah, Tenti., Hairida., Rawmawan, Rahmat. Keterampilan Bepikir Kritis Siswa Menggunakan Model Pembelajaran Inkuiri Terbimbing pada Materi Asam Basa. Jurnal Pendidikan dan Pembelajaran UNTAN, 4 (6). 2015.

[6] Susanto, A. Teori Belajar dan Pembelajaran di Sekolah Dasar. Jakarta: Prenadamedia Group. 2015.

[7] Dipalaya, Tismi dkk.. Pengaruh strategi pembelajaran PDEODE (Predict-Discuss-Explain-Observe-Discuss-Explain) pada kemampuan akademik berbeda terhadap keterampilan komunikasi siswa. 2016. Jurnal Pendidikan, 9 (1), 1713-1720.

[8] Khanthavy \& Yuenyong. 2009. The Grade 1 Student's Mental Model Of Force and Motion Through Predict-Observve-Explain (POE) Strategy. Paper. Online. Tersedia di http://www.recsam.edu./ [diakses 02-01-2018].

[9] Costu, B. Learning Science through The PDEODE Teacing Strategy: Helping Student Make Sense of Everyday Situations. 2008. Eurasia Journal of Mathematics, Science, and Technology Education. 2 (2): 96-114.

[10] Orgill, M. \& Sutherland, A. Undergraduate Chemistry Students' Perception of and Misconception about Buffer and Buffer Problems. 2008. Chemistry Education Research and Practice. 9, 131-143.

[11] Sugiyono. Metode Penelitian Pendidikan: Pendekatan Kuantitatif, Kualitatif dan R\&D. Bandung: Alfabeta. 2015.

[12] Solichah, I., Tukiran, dan Subekti, H.. Penerapan Strategi Pembelajaran PDEODE untuk Mereduksi Miskonsepsi Siswa. 2014. Jurnal Pendidikan Sains e-Pensa, 2 (2): 308-316.

[13] Sudarmi, Nym., Suarni, Dibia. Pengaruh Model Pembelajaran PDEODE terhadap Hasil Belajar IPA Siswa Kelas IV SD di Gugus V Kecamatan $\quad$ Seririt, 2013. (http://ejournal.undiksha.ac.id/index.php/JJPGSD/article/viewFile/71 $2 / 585)$ 